\title{
Ditch-blasting as a method of opening-up tropical swamp forest in Surinam
}

\author{
F. C. BUBBERMAN and A. T. VINK \\ Surinam Forest Service, Paramaribo, Surinam
}

\section{Summary}

In the extensive swamp forests of the coastal area of Surinam, the commercially important, peeling timber Virola surinamensis forms locally what might be termed "virola stands" (density 1-7 trees per ha). These total some 100,000 ha in 5 stands, varying in size from 6000 to over 40,000 ha each. They form a part of the vegetation type "high swamp forest" and occur mainly on flat, marine sediments, geologically belonging to the young coastal plain between the higher, eroded remnants of the old coastal plain. Soils consist of heavy clay, covered with a peat layyer varying from less than $1 / 2 \mathrm{~m}$ to over $2 \mathrm{~m}$ in thickness.

The $20-30 \mathrm{~m}$ high, open virola forest contains only two or three emergent tree spp. besides Virola and a sub-canopy of a palm species. On special $1: 10,000$ aerial photographs the individual mature (ca. $40 \mathrm{~cm}$ diameter and over) virola trees can be identified with reasonable accuracy, once an identification key has been prepared in the field. Dot maps are prepared to show the position of the mature trees. The Forest Service has to date inventoried three virola stands, totaling 37,000 ha.

To open up these stands for logging the Forest Service constructs $3-4 \mathrm{~m}$ wide and $3 / 4-1 \mathrm{~m}$ deep ditches through the swamp by blasting with dynamite in a $10-20 \mathrm{~m}$ wide track, cut and partly cleared by hand. Explosives, tools, site preparation and working technique are described. Blasting proceeds only in the two dry seasons. Construction costs vary from $\mathrm{S} f 5500$ to $\mathrm{S} f 7500$ per $\mathrm{km}$ $(1 S f=$ US $\$ 0.54)$. During the rainy seasons virola logs are floated through the ditches out to the river, for rafting and transport to the plywood factory. The waterlevel in the ditcines is regulated by permanent wooden weirs and floodgates.

Between 1958 and 1963 the Forest Service blasted $61 \mathrm{~km}$ of ditch to open up some 23,000 ha virola forest ( 2 swamp-forest stands). A private timber company constructed $23 \mathrm{~km}$ ditch in another virola stand.

Surinam experience shows, that ditch-blasting for forest-exploitation purposes is a suitable technique in the clayey soils of the swamp forests, provided the peat layer is not unduly thick.

Litter and weeds gradually block the ditches, which have to be maintained by opening the weirs (scouring action of the current), manual removal of the weeds or by spraying with herbicides.

In the deep and fairly clean ditch sections through clay, weeds are much less troublesome than in the shallow sections through peaty soil. Overhead shade eventually kills the weeds.

It is advisable to let blasting proceed apace with exploitation in order to make effective use of the ditches and reduce maintenance costs.

\section{Preface}

During the past years the Surinam Forest Service has obtained experience with ditchblasting as a method of opening-up valuable, but hitherto inaccessible, swamp forests. As far as the authors are aware the subject of ditch-blasting in forest exploitation

Received for publication 6th August, 1965. 
has never been discussed in a technical paper, though the Surinam ditch-blasting work has been briefly mentioned in some noies (ANON., 1962; Surinam Forest Service, 1958-1963). As ditch-blasting might provide a possible solution to forest-transportation problems elsewhere, we felt that a fuller discussion of the technique was warranted. It should be emphasized that ditch-blasting is a useful technique in agriculture as well and was, in fact, developped for that purpose. Explosives are suitable in agricultural engineering, such as providing drainage in waterlogged terrain, wherever working conditions restrict the use of ordinary earth-moving equipment.

In the following pages a somewhat elaborate description is presented of soil and vegetation in the Surinam swamp forests, to enable the reader to evaluate the practicability of this construction method under local conditions.

\section{Swamp forests}

\subsection{General}

Surinam $\left(162,900 \mathrm{~km}^{2}\right)$ is situated on the northeastern coast of South America in the "tropical lowland rainforest" zone. Mean daily air temperature remains fairly constant throughout the year at about $26^{\circ} \mathrm{C}$. Mean annual rainfall lies between 2000 and $2400 \mathrm{~mm}$ with main rains from April to July, main dry season to November, and less sharply defined, short wet and dry seasons fitted in between December and April. Two broad geological divisions are recognized:

a. Basement complex (Archaic to Paleozoic age), exposed mainly in the densely forested upland region which makes up $4 / 5$ of Surinam.

b. Young deposits, divided into:

- the White Sand series in the lowland region,

- the Coastal Sedimentary series in the coastal belt.

Roughly speaking the Young Deposits form continuous belts more or less parallel with the Atlantic cocast, though narrower in the east and widening towards southwest. Soil types and vegetation tend to follow the main geological pattern.

The infertile sands and loams of the White Sand series bear different types of xerophytic vegetation. On the fertile clays of the coastal alluvium the swamp forests are found which are the subject of this paper. The coastal plain, about $21,000 \mathrm{~km}^{2}$ in all, is an almost level landscape, partly inundated because of impeded drainage, and covered with various types of hygrophytic vegetation. The population of Surinam $(325,000)$ is largely concentrated in the coastal area.

\subsection{Landscape and soils of the coastal plain}

Pedologically the coastal plain is divided (from north to south) in the young coastal plain and the old coastal plain.

The young coastal plain consists of sea clay, situated at or below the high water mark, upon which locally sand and shell ridges have been deposited at former coastlines. These long, low and narrow ridges occur individually or in bundles and are mainly found in central and eastern Surinam.

The old coastal plain is essentially a repetition of the landscape elements of the young coastal plain, but older, more eroded and at a higher elevation, to about $10 \mathrm{~m}$ above sealevel.

It consists of dry, fine sandy areas and marshy patches of irregular shape with a silty soil. The sandy and silty complexes are separated by low level creek systems and swamps with a clay soil, in age and origin belonging to the young coastal plain. 
Like the young coastal plain, the old plain was formed by marine sediments laid down in a shallow sea behind off-shore bars. Successive re- and transgressions of the sea have modified the original landscape to a much greater extent than in the young coastal plain. The young swamps between the old islands in the clay landscape point to a transgression, the difference in elevation between old and young coastal plain indicates a considerable subsequent regression.

\subsection{Vegetation of the coastal plain}

Generally speaking an accretion of land is in progress in the coastal area by sedimentation, accumulation of organic matter, or both. As the accretion proceeds the pioneer herbaceous vegetation gradually changes to low swamp forest, high swamp forest and, eventually, marsh forest. Sea or fire may retard or reverse the process. Apart from the ridges which bear mainly a type of high forest, natural vegetation in the coastal area consists exclusively of hygrophytic vegetation types, characterized by their simple structure and poverty in species.

Of the hygrophytic vegetation types the high swamp forest is of interest within the context of this paper.

\subsection{High swamp forest}

As the last intermediate stage in the succession from open swamp to marsh forest, i.e. the high swamp forest, is found on the older parts of the young coastal plain and on the old coastal plain, especially on the old clay landscape. The forest type makes up about $36 \%$ of the coastal forests or about $4 \%$ of Surinam's total forest area.

Soils consist of heavy, grayish, sometimes silty clay. The swamp forest is waterlogged for the greater part of the year and remains at least damp in the long dry season. In the main rainy season the forest is inundated to a depth of $1 \mathrm{~m}$ and more in places. Incompletely decomposed organic matter accumulates in a layer of peat locally termed "pegasse" - on top of the clay, wherever the highly acidic, stagnant water produces the necessary anaerobic conditions. The pegasse layer varies in thickness from $1 / 4-3 / 4 \mathrm{~m}$ to over $2 \mathrm{~m}$ in former erosion gullies.

In extremely dry years the pegasse may dry out completely and constitute a considerable fire hazard. In 1963-1964 vast swamp forest areas fell victim to mancaused pegasse fires.

The high swamp forest is a two-storied forest type; the upper story ranges from $20-30 \mathrm{~m}$ in height, the under story consists of saplings of the canopy species and some palms, one of which (Euterpe) also reaches canopy size. The swamp forest trees are flat-rooted species, adapted to their habitat by mechanical supports: buttresses, like Virola surinamensis, Pterocarpus officinalis; stilt roots like Symphonia globulifera, large rootclumps like the palm species Euterpe oleracea and Mauritia flexuosa. Other common swamp trees are Triplaris surinamensis and Tabebuia species.

The swamp forest is poor in species: the longer the period of complete inundation, the lower the number of species.

Stem counts in the fairly open stand range from 110-130 trees (over $25 \mathrm{~cm}$ diameter) per ha, with a basal area of about $13 \mathrm{~m}^{2}$ per ha.

\subsection{Virola forest}

In some high swamp forest complexes Virola surinamensis is one of the dominant canopy species to such an extent that these stands may be termed "virola forest". 
Characteristic canopy species in the virola stands are Symphonia globulifera, Ptero. carpus officinalis, Tabebuia insignis, var. monophylla and the palm Euterpe oleracea. FIG. 1 and 2 show a view and a profile of a virola stand, respectively.

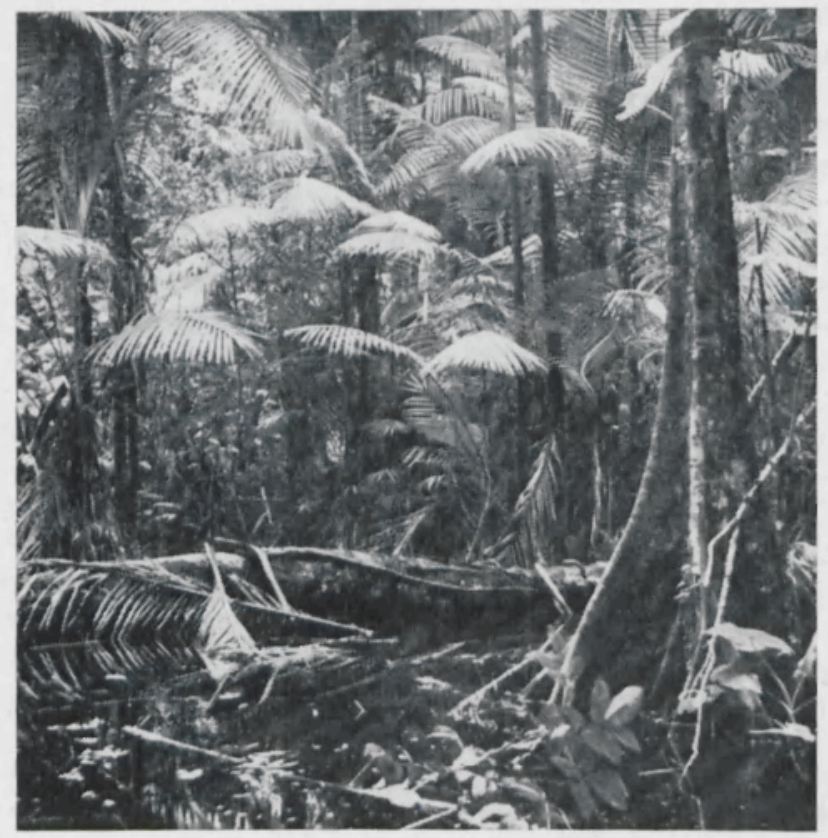

FIG. 1

The high swamp forest

TABle 1. Landscapes, soils and vegetation types in the Surinam coastal area

\begin{tabular}{|c|c|c|c|c|c|}
\hline $\begin{array}{l}\text { Geological } \\
\text { division }\end{array}$ & $\begin{array}{l}\text { Type of } \\
\text { soil }\end{array}$ & $\begin{array}{l}\text { Pedological } \\
\text { formation }\end{array}$ & Landscape & $\begin{array}{l}\text { Vegetation } \\
\text { type }\end{array}$ & Area \\
\hline \multirow{5}{*}{$\begin{array}{l}\text { Young } \\
\text { deposits }\end{array}$} & \multirow{2}{*}{$\begin{array}{l}\text { young } \\
\text { sediments }\end{array}$} & \multirow{2}{*}{$\begin{array}{l}\text { Demerara } \\
\text { (young coastal } \\
\text { plain) }\end{array}$} & ridge landscape & ridge forest & \multirow[t]{4}{*}{ Coast } \\
\hline & & & clay landscape & $\begin{array}{l}\text { mangrove forest } \\
\text { open swamp } \\
\text { swamp forest }\end{array}$ & \\
\hline & \multirow[t]{3}{*}{$\begin{array}{l}\text { old } \\
\text { sediments }\end{array}$} & \multirow[t]{2}{*}{$\begin{array}{l}\text { Coropina } \\
\text { (old coastal } \\
\text { plain) }\end{array}$} & $\begin{array}{l}\text { old ridge } \\
\text { landscape }\end{array}$ & $\begin{array}{l}\text { ridge forest } \\
\text { marsh forest }\end{array}$ & \\
\hline & & & $\begin{array}{l}\text { old clay } \\
\text { landscape }\end{array}$ & $\begin{array}{l}\text { marsh forest } \\
\text { swamp forest } \\
\text { Virola forest }\end{array}$ & \\
\hline & & Zanderij & cover sands & savanna & Interior \\
\hline $\begin{array}{l}\text { Basement } \\
\text { Complex }\end{array}$ & $\begin{array}{l}\text { residual } \\
\text { soil }\end{array}$ & & $\begin{array}{l}\text { granites } \\
\text { schists }\end{array}$ & $\begin{array}{l}\text { high forest } \\
\text { marsh forest }\end{array}$ & \\
\hline
\end{tabular}


DITCH-BLASTING, A METHOD OF OPENING-UP TROPICAL SWAMP FORESTS

Fig. 2. Profile of a virola stand. (After Lindeman and MoolenaAr, 1959)

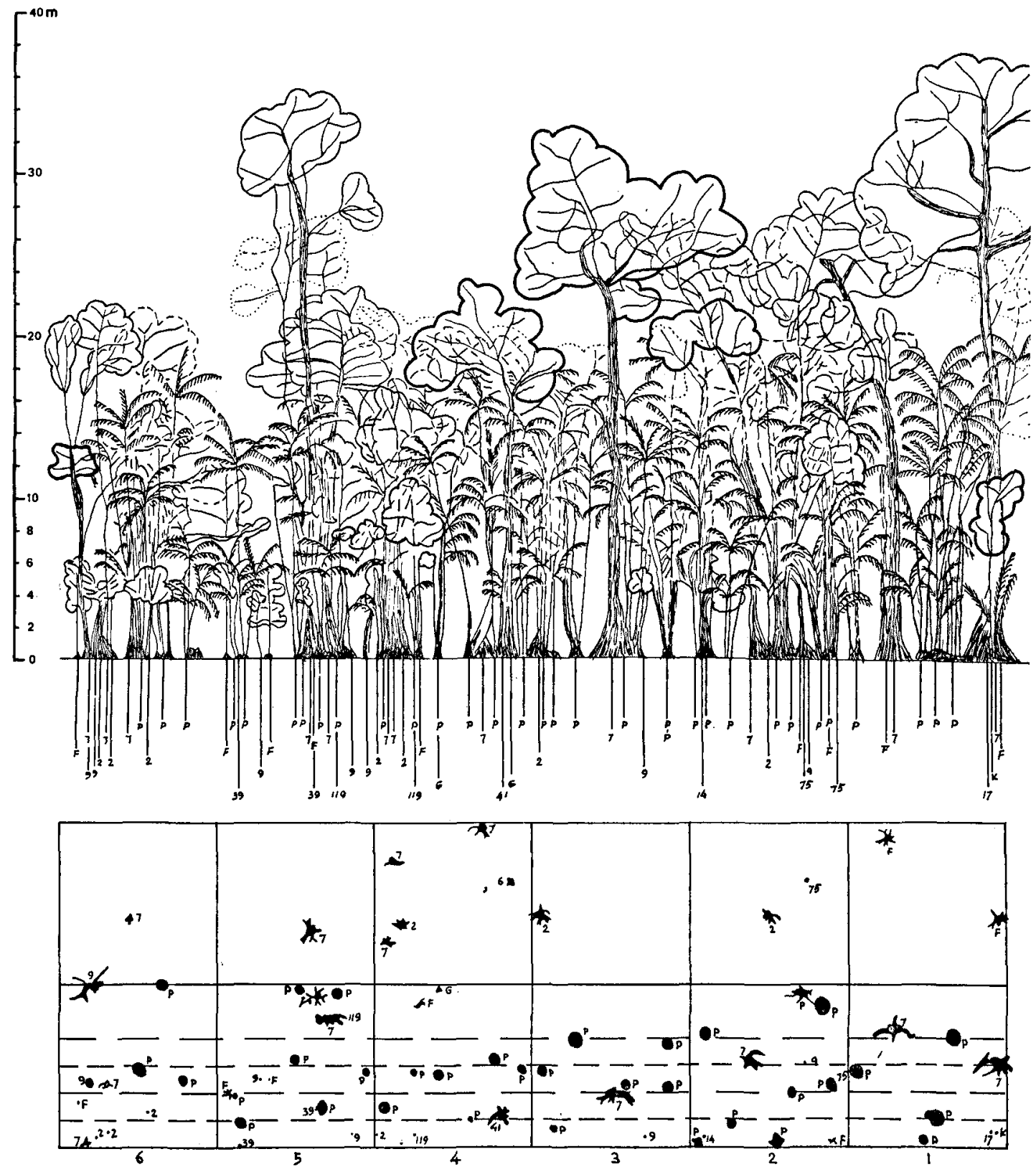

Profile II - Swamp forest type B

2 Pterocarpus officinalis F Symphonia globulifera

7 Virola surinamensis G Tabebuia insignis var. monophylla

P Euterpe oleracea

Neth. J. Agric. Sci., Vol. 14 (1966) No. 2 (May) 
The virola stands - five in all ranging in size from 6000 ha to over 40,000 ha and totaling $100,000 \mathrm{ha}$ - are found mainly on the low-lying areas formed by erosion of the clay landscape of the old coastal plain. Remnants of the original plain are now present as irregular shaped, higher islands bearing marsh forest or high forest, in the surrounding swamp.

TABLE 1 summarizes landscapes, soils and vegetation types in the coastal area and shows the position of the virola forests in the general scheme.

Virola surinamensis, locally known as "baboen", is common to frequent in the high swamp forest and common in marsh and riparian forest. Its range includes the Amazon region of Brazil, the Guianas, Venezuela and parts of the West Indies.

Virola is a tree with spreading plank buttresses. It attains a height of $30-35 \mathrm{~m}$ and a diameter of $60-70 \mathrm{~cm}$, occasionally to $90 \mathrm{~cm}$. The usually straight, cylindrical bole is $15-20 \mathrm{~m}$ long.

The light, pink-brown virola wood has gained reputation as an excellent peeling timber and the virola stands have developed into a valuable source of raw material for Surinam's plywood industry (1963 value of virola plywood exports: US \$ 2.3 million, or roughly $5 \%$ of total Surinam exports). These facts sufficiently explain the importance of finding methods to inventory and open up the virola reserves.

\section{Inventory}

\subsection{Interpretation of aerial photographs}

Because of terrain conditions extensive terrestrial inventories in the swamp forests are a difficult proposition, so that aerial photographs (AP) have to be used to the fullest possible extent.

Of the entire northern part of Surinam aerial photography is available on scales $1: 40,000$ and $1: 20,000$. On these scales the forest types are readily discernable, but individual tree species only rarely. In the even-textured virola forest with its lowcontrast photo image, identification of single tree species is out of the question.

However, experiments indicated that on 1 : 10,000 airphotos the canopy shows up in sufficient detail to permit distinction of separate trees and - in the floristically poor virola forest - identification of individual tree species. In 1956-1960 photographic coverage on scale 1 : 10,000 was prepared for all major virola complexes.

By means of a field reconnaissance the photo image can be compared readily with the crown structure as seen from below, without interference from intermediate stories, and the construction of a photo-interpretation key poses no problems. Once an interpretation key is completed for a given area, the entire stand may be inventoried easily and accurately by marking with a dot all virola trees visible on the photos and tallying the trees in 100 ha squares. The dots are also transferred to 1 : 10,000 dot maps which clearly show the location of the richest virola concentrations and serve as a basis for exploitation planning (see FIG. 3).

So far, Virola inventories have been completed in respect of three stands.

$\begin{array}{lccc}\text { Area } & \text { ha } & \begin{array}{c}\text { No. of Virola } \\ \text { trees }\end{array} & \begin{array}{c}\text { Estimated merchant- } \\ \text { able volume }\left(\mathrm{m}^{3}\right)\end{array} \\ \text { Rorac } & 11,300 & 41,000 & 78,000 \\ \text { Perica } & 13,800 & 37,400 & 75,000 \\ \text { Tibiti } & 11,900 & 11,300 & 19,000\end{array}$


Fig. 3. Stereo-pair of $1: 10,000$ aerial photographs of the Rorac virola stand; map on left shows results of photo-interpretation of this stereo-pair. Each dot represents a virola tree identifiable on the photographs by the lighter-toned, rounded crown. The coarser canopy image near top of the photo indicates a marsh-forest island in the swamp
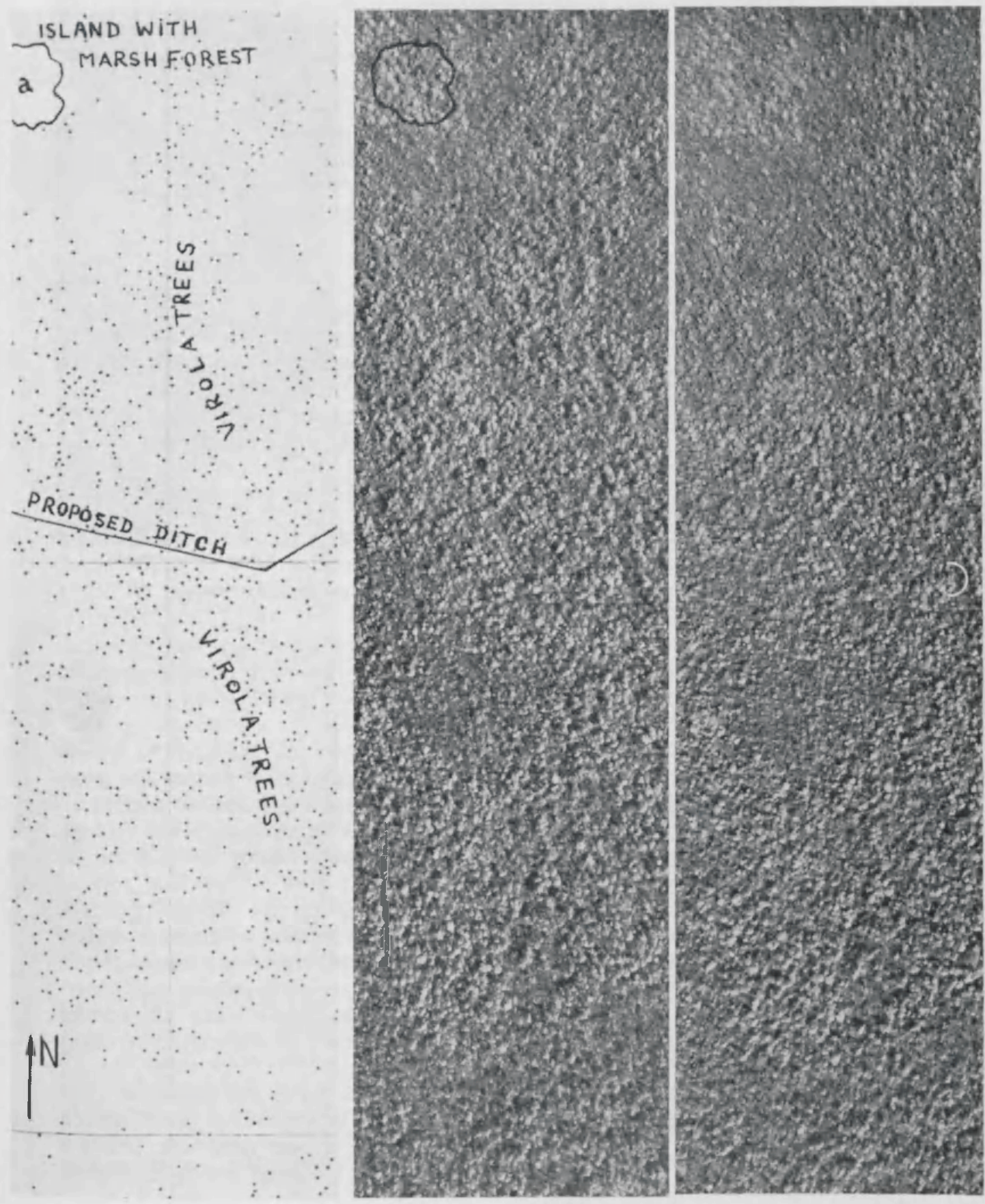


\subsection{Accuracy of the photo-inventory}

Apart from the experience of the interpreter the interpretation error depends mainly on the floristic composition of the particular stand.

Presence of other canopy species affects interpretation results in a different way in each locality, depending on the composition of the stand, e.g. the swamp-forest species Tabebuia insignis. This closely resembles Virola on the aerial photographs and becomes increasingly frequent towards western Surinam.

Photo quality and position of the sun at the time of photographing greatly influence image tone and contrast and thereby interpretation results.

Although photo interpretation reduces field work considerably, terrestrial checking of interpretation results always remains necessary. Comparison of photo-inventory with subsequent field tally in two sample plots, totalling 34 ha, showed:

a. About $70 \%$ of the trees classified as Virola by a trained observer, are identified correctly, $30 \%$ belongs to other species.

b. The total number of visible - and potentially identifiable - virola trees on the photographs equals or exceeds the number of trees identified as Virola (whether correctly or incorrectly). In other words, photo interpretation yields a conservativa estimate of the actual stand density.

c. Interpretation accuracy increases with the diameter of the trees.

d. Trees over $40 \mathrm{~cm}$ diameter, i.e. of merchantable size, are always visible on the photographs.

e. Fairly often several virola trees grow close together and are interpreted as a single tree on the photo.

The conclusion of the sample-plot data is, that interpretation of $1: 10,000$ aerial photographs gives a fairly accurate estimate of the density and distribution of Virola of merchantable size.

\section{Ditchblasting}

\subsection{Ge nera 1}

Virola timber floats and the stands are inundated during at least part of the year, so, obviously, water transportation was and is the main extraction method (FIG. 4). The easily accessible Virola near the river banks had been removed years ago through hand-dug trenches. Faster and more efficient methods were needed to open up the extensive virgin stands away from the rivers.

In N. America, Scandinavia and elsewhere ditch-blasting, i.e. the use of explosives instead of mechanical tools, is a well-known construction method of drainage ditches in level, waterlogged terrain. Dynamite disposes easily of vegetation, stumps, boulders and similar obstructions that would handicap ordinary earth-moving machinery. The method is versatile, easily adapted to needs and no heavy initial expenditure for capital equipment is required, nor workshops and skilled mechanics for its maintenance.

Ditch-blasting consists essentially in placing explosive charges in the ground at fixed intervals along the centre line of the proposed ditch. The expanding gasses formed by the explosion throw out the earth in all directions, a part falls back into the ditch, but most of it is thrown clear, so that a $\mathrm{V}$ - or $\mathrm{U}$-shaped trench is formed, 
FIG. 4. Crews and explosives move through the ditch to the loading site

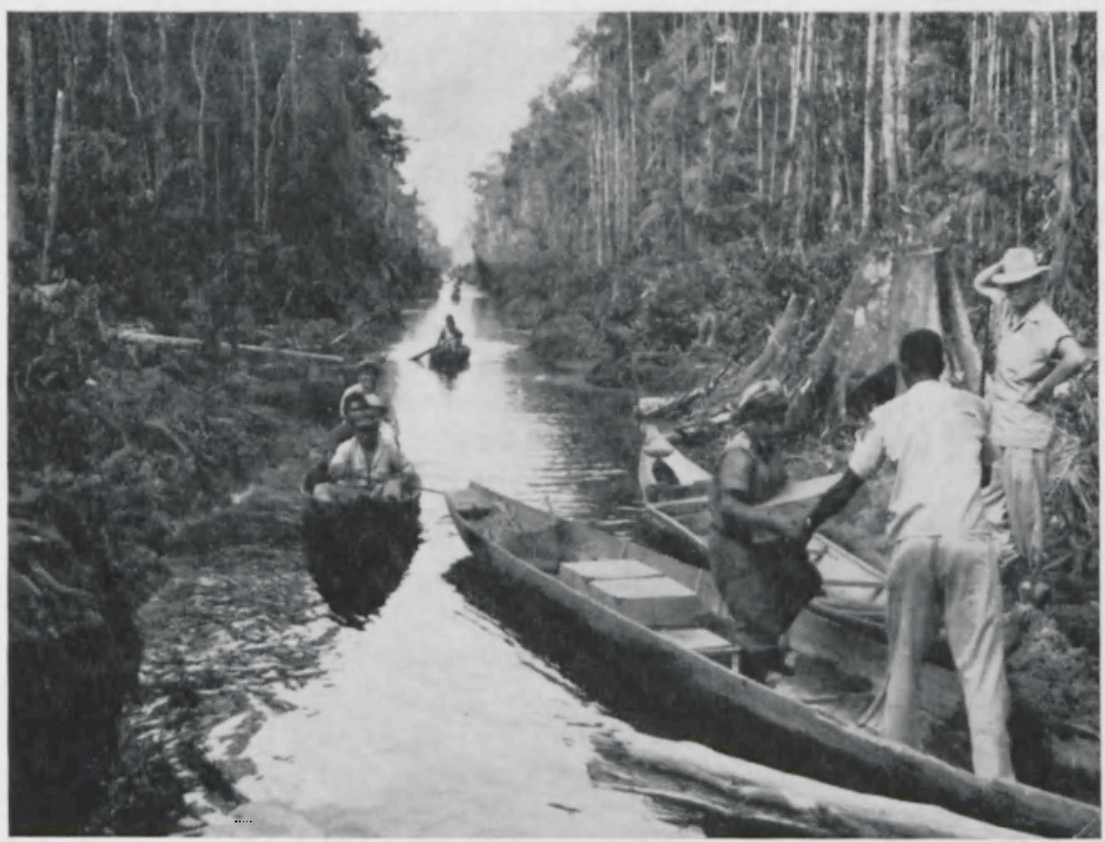

the width and depth whereof are determined by soil conditions and the weight of the charge. Distance between the loaded holes depends on the size of the individual charges. In ditch-blasting the individual charges are usually exploded by propagation: only one charge is primed and fired, electrically or with safety fuse, the concussion of the exploding primer charge is forcefully propagated through the wet or moist soil, setting off all the other charges.

In dry soil propagation blasting is not feasible and all individual charges must be fired simultaneously, by means of electric blasting caps or detonating fuse.

As propagation firing is both cheaper and simpler than individual ignition of all charges, it should be used whenever soil-moisture conditions permit it.

When the soil is sufficiently cohesive to stick together when moulded in the hands it is moist enough to allow propagation blasting. Insufficient moisture seriously reduces propagation distance, additional moisture permits greater intervals between charges.

\subsection{Ditch-blasting in Surinam}

Experiments in this direction seemed indicated, the more so, because all conditions for successful ditch-blasting are fulfilled in the virola swamps: fairly level terrain, high soil-water table and a firm subsoil fairly close to the surface.

Trial shots gave satisfactory results and in 1958 the Surinam Forest Service started a project of systematic ditch-blasting to open-up the "Rorac" stand (39-km ditch, blasted between 1958 and 1961) and the "Perica" area (22-km ditch, 1961-1963). 
Meanwhile a private logging company blasted $23 \mathrm{~km}$ of ditch in the "Tibiti" virola stand.

Ditches are projected on the inventory dot maps (FIG. 3) to tap the richest virola concentrations and bring all parts of the stand within reach of exploitation. In order to serve their purpose as extraction channels to float out logs to the river, they have to be $3-4 \mathrm{~m}$ wide and $3 / 4-1 \mathrm{~m}$ deep in the rainy season.

The information on ditch-blasting in engineering handbooks is borne out by the experience obtained by the Forest Service. Blasting through soft peat gives poor results and ditching with explosives is practically impossible in sand or fine gravel. In Surinam satisfactory blasting have been made in very fine sandy soils, but resulting ditches silt up again within a short time.

The following notes describe ditch-blasting technique in general with special reference to experiences in the Surinam swamp forests.

\subsection{Explosives, a c essories, tools}

\subsubsection{Explosives ${ }^{1}$}

Ditching Dynamite (referred to as DD in this paper) is a high explosive containing $50 \%$ nitroglycerine in an absorbing medium. Manufactured especially for ditchblasting, DD is highly shock-sensitive and water-resistant, enabling it to be fired by propagation in moist or wet soil. It is expensive and somewhat hazardous to handle on account of its sensitivity. In Surinam it. was used in 50-1b. cases, containing about 100 cartridges ("sticks"), each of $1 / 2 \mathrm{lb}$. and $11 / 4^{\prime \prime} \times 8^{\prime \prime}$ in size.

In Red Cross Extra dynamites (RC) part of the nitroglycerine is replaced by ammonium nitrate, to render them cheaper and less sensitive, i.e. safer to handle. RC $50 \%$ strength has adequate water resistance for use in ditch-blasting work, but $\mathrm{RC}$ cannot be fired safely by propagation and must be ignited by means of a DD stick placed alongside, or with blasting caps. In Surinam it was mainly used in 5-1b. cartridges, size $3^{\prime \prime} \times 16^{\prime \prime}$, to blast out stumps etc. in the right of way.

Blasting agents, cheaper and safer still than RC, contain no nitroglycerine at all. Highly insensitive and not water-resistant they can be used only in dry boreholes and must be ignited with high explosives or suitable primers. The Surinam Forest Service has a limited, though favourable experience with blasting agents in blasting through a high, fine sandy ridge.

To avoid long delivery times and high shipping costs the Surinam Forest Service ordered its explosives through regular shipments to a local mining company.

\subsubsection{Accessories}

Blasting caps, small metal tubes, containing a highly-sensitive explosive, designed to ignite the main explosive charge when fired electrically (electric blasting caps) or from the sparks of safety fuse.

Safety fuse, a combustible core within protective wrapping. Burning slowly when lit, it gives the blaster time to retreat while it carries the flame to a blasting cap and primer charge affixed to the other end.

Detonating fuse, an explosive core with protective covering. When lit - electrically or with a common blasting cap and fuse - it detonates, igniting in turn all other explosive charges it is placed in contact with.

1 Brand names refer to American and Canadian explosives. 
Cap crimping plier, specially designed to trim fuse and crimp-blasting caps to the fuse.

\subsubsection{Loading tools}

Tools are necessary to make the charge holes, to space them at the correct distance and to load the explosive into the hole.

Soil punches of wood or metal are suitable to punch shallow holes in soft soil to accommodate a single cartridge.

Hollow core punch bars are generally used to make holes up to $0.75-1 \mathrm{~m}$ deep in firmer soil or in soil obstructed by roois. The tool consists of a hollow rod, $4-5 \mathrm{~cm}$ or so in diameter with handles, which is driven into the ground by means of repeated blows of a weighted punch bar, inserted through the hollow rod. Punch bars are available in several types: the type used in Surinam is illustrated in FIG. 5 and 6. It can be constructed from iron pipe and rod in any blacksmith shop. Punch bars tend to break at the most inconvenient moments and an ample supply should be kept on hand when loading is in progress.

In the Forest Service ditch-blasting work it was found advantageous to use two rods to each punch bar, one rod being rammed down while the previous one is being loaded with dynamite. The explosive is tamped with the wooden tamping stick and the hollow rod is removed over the stick. This arrangement prevents any cartridge from sticking to the inside of the rod, or the punch bar from being inadvertently inserted once more into an already loaded hole, both with disastrous consequences (see FIG. 7).

Posthole soil augers with a diameter of $7^{1 / 2}-15 \mathrm{~cm}$, either hand- or engine operated, are useful for drilling holes to $1-1.2 \mathrm{~m}$ deep in drier clayey soil, for blasting by the so-called "posthole method" (see below). Sometimes the hole must be started with a spade to cut through a zone of interlaced roots.

Wooden tamping sticks are simply rounded sticks, about $1 \mathrm{~m}$ long, with squared ends, used to push the dynamite cartridges into the charge holes. (This should never be done with any sparking metal tool.) The stick may be graduated to ensure loading to a uniform depth.

A simple measuring stick is used to space the individual loads at the correct distance.

\subsection{Site preparation}

The ditch system as projected on the virola-dot maps (FIG. 3) prepared from the AP's, is surveyed in the field with compass and chain and the trace is staked out. Levelling had to be undertaken in some cases. Separated from the tidal lower rivers, the swamp forest areas are drained by natural, winding, sluggish watercourses, hardly discernable at times, that eventually find their way to the river by way of a swamp creek or by way of a tidal channel through the river levee.

In the Rorac project levelling showed a height difference of $3 \mathrm{~m}$ between the river and the swamp only $21 / 2 \mathrm{~km}$ inland. In this case a series of weirs with floodgates had ot be constructed in the access canal from the river.

In the Perica project a branch ditch was projected to cross an existing shallow drainage channel. Levelling revealed the latter to be lower in elevation than the main entrance to the ditch network, so that the ditches would have been drained empty in an entirely unwanted direction if the proposed connection had been constructed.

Originally all trees were felled in a $20-\mathrm{m}$ wide strip and all small trunks and felling 


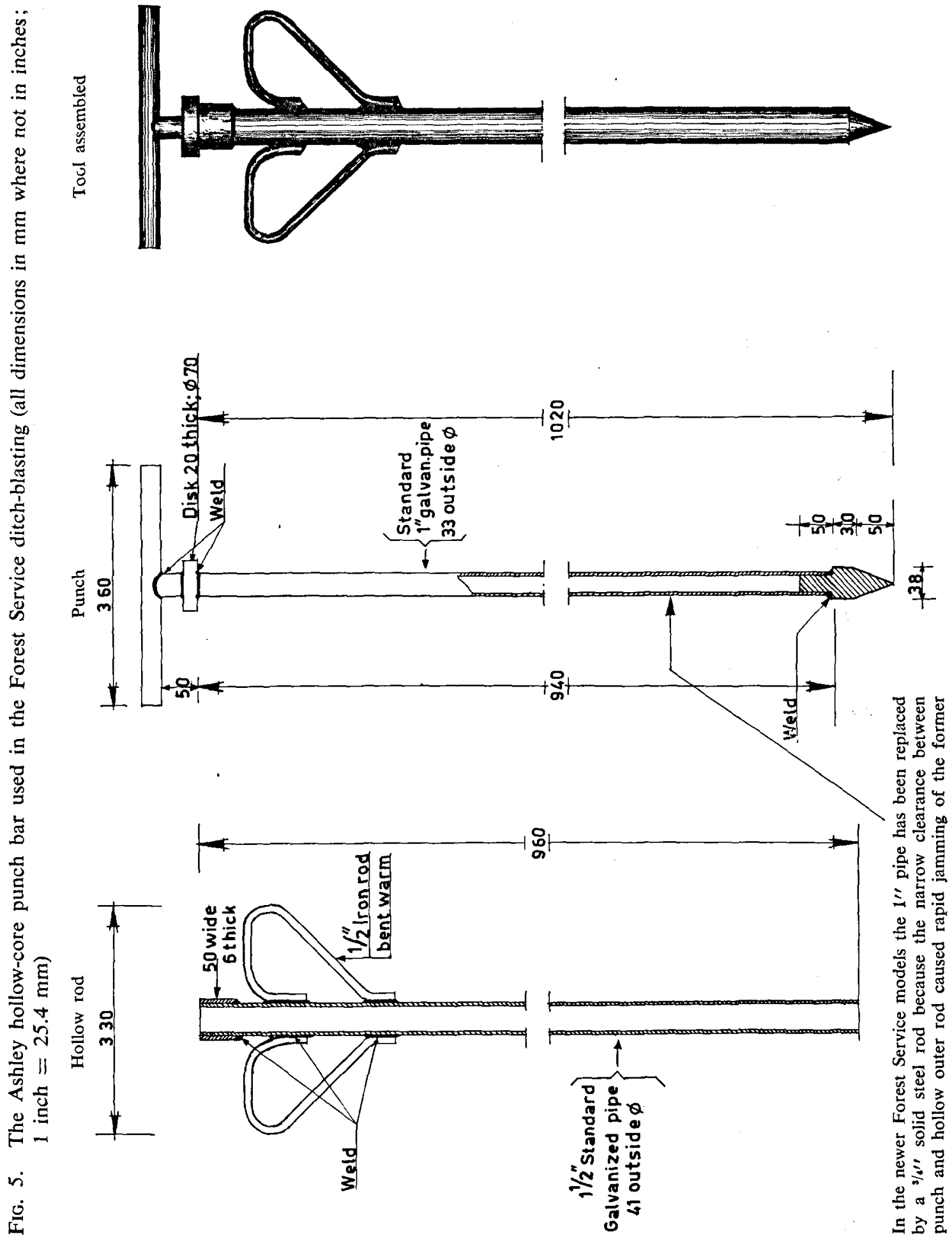




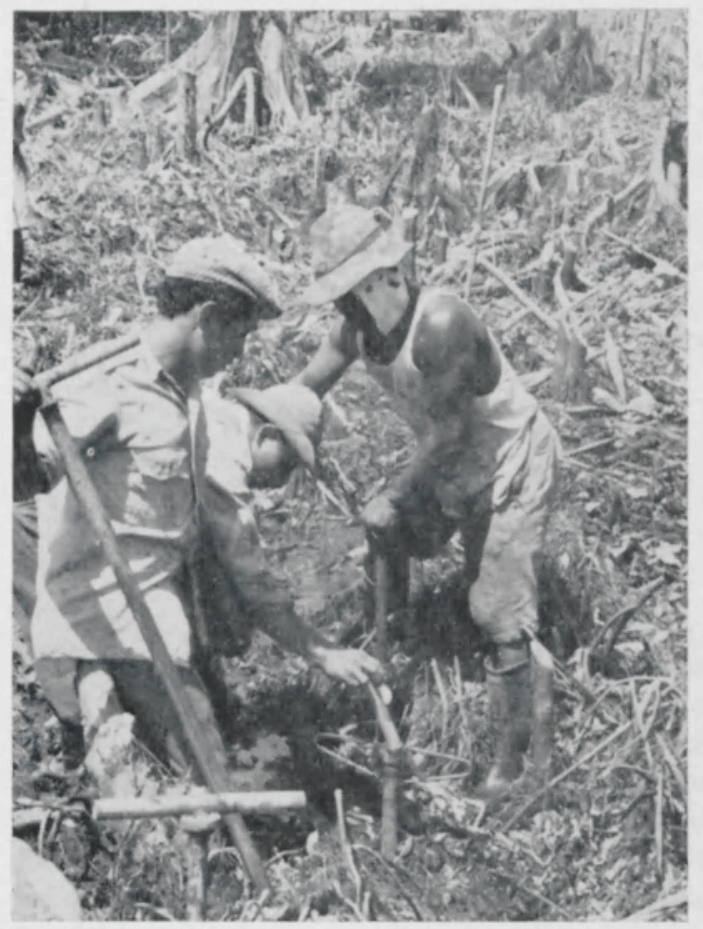

FIG. 6

Punching and loading, one rod being rammed down while the previous one is loaded with sticks of Ditching Dynamite (DD)

slash removed in the central $10 \mathrm{~m}$ zone. Subsequent trials in $10-\mathrm{m}$ wide strips with only the axis cleared of felling debris were satisfactory, though ditch-cleaning costs increased slightly. This system became standard practice from 1962 onwards. To facilitate the transportation of dynamite through the rough and often waterlogged strip a "path" of palm trunks is always constructed along the track.

\subsection{Working te ch n ique}

For rough calculation it may be assumed that $1 \mathrm{lb}$. (454 $\mathrm{g}$ or 2 sticks) of $50 \%$ DD will move ca. 1 cubic yard of material (about $3 / 4 \mathrm{~m}^{3}$ ); in heavy, compact clay this is reduced to about $2 / 3$ cubic yard $\left(1 / 2 \mathrm{~m}^{3}\right)$, in light, loose soil it is increased.

On this basis specifications may be drawn up for single-line, cross-section and posthole loading, according to soil and size of desired ditch. Loading schedules will be found in any handbook on blasting. It must be emphasized that much depends on soil and vegetation conditions. Test shots are the only reliable way to determine the correct amount and distribution of the explosive.

Surface water must be taken into account in the same way as the soil itself when necessary loads are computed. Therefore ditch-blasting in deeply-inundated swamp is uneconomic. In Surinam blasting proceeded mainly in the dry seasons.

\subsubsection{Loading}

Single-line method. One or more DD cartridges depending on the soil and the size of ditch required, are placed in a column in a single row, at distances of $35-55 \mathrm{~cm}$, depending on the charge. The top of the uppermost cartridge should be $15-30 \mathrm{~cm}$ below groundlevel (see FIG. 8a). 


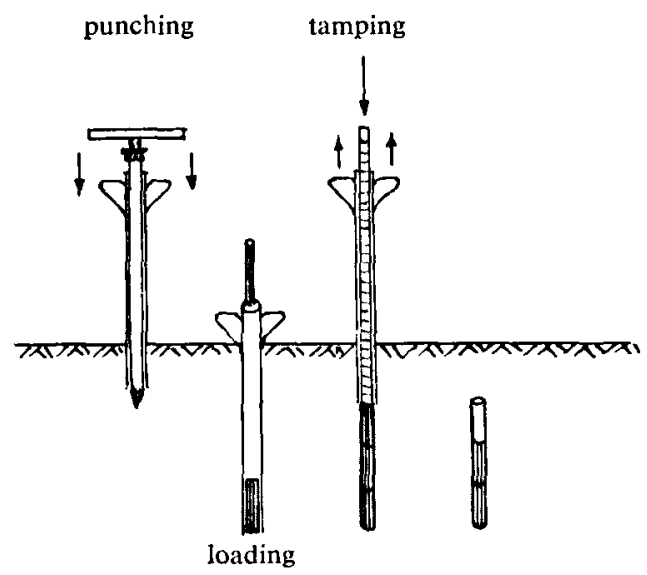

FIG. 7

Schematic sequence of punching and loading

Cross-section method. Essentially the same as the single line method, but with crossrows offset at right angles from every other hole on the centre line. The centre holes are usually loaded heavier than the cross-rows. The system is suitable to obtain wider ditches or to break a heavy, tangled root mat, such as found in the Surinam swamp forest in patches where Symphonia globulifera abounds (see FIG. 8 b).

Most of the Forest Service ditches have been shot by the single-line column load method, with an occasional cross-row to break a heavy root mat. Loads of 2,3,2,3,2 etc. DD sticks at intervals of $45 \mathrm{~cm}$ were usually adequate to produce a ditch of required width $(3-4 \mathrm{~m})$ and depth $(3 / 4 \mathrm{~m})$. In heavier soil or to blast through slightly higher portions of the swamp $3,4,3,4,3$ etc. loads have been used to advantage. Heavy tree stumps are usually loaded with one or more $5-1 \mathrm{~b}$. RC cartridges.

Loading is done by a crew of three: a porter to carry the dynamite cases to the loading site, a puncher and a loader. One porter can keep pace with two loading crews if carrying distance is short. One crew loads $100 \mathrm{~m}$ a day.

The actual loading of the set task seldom takes over 3-4 hours, the remainder of the working time is spent in travelling to and from the work, by corials (dug-out canoes) through the ditches to the campside near the river.

Posthole method. An effective way to blast deep ditches, especially in heavier, compact types of soil, postholing consists in placing charges of several pounds in augerdrilled holes, at $2 / 3$ the depth of the required ditch and spaced $0.9-1.2 \mathrm{~m}$ apart, depending on the charge. The loads are fired by propagation or by individual ignition (detonating fuse, electric caps). Because of its fewer but heavier charges per unit length as compared with the other two methods, postholing is a suitable ditchblasting method in dry conditions, where all individual charges must be ignited (see FIG. $8 \mathrm{c}$ ).

In Surinam the posthole method was used to advantage when it was necessary to extend the ditch through higher, relatively dry sections of the swamp. Holes are dug with spades, punched with heavy sticks or drilled with soil augers. The loads are usually made up in part of 5-1b. RC cartridges, each accompanied at least one stick of $\mathrm{DD}$ to ensure detonation. Ignition is by propagation or with detonating fuse, depending on soil moisture content. 
FIG. 8. Loading patterns (all dimensions in $\mathrm{cm}$ where not in inches; 1 inch = $2.54 \mathrm{~cm}$ ) a. single-line, b. cross-row, c. posthole
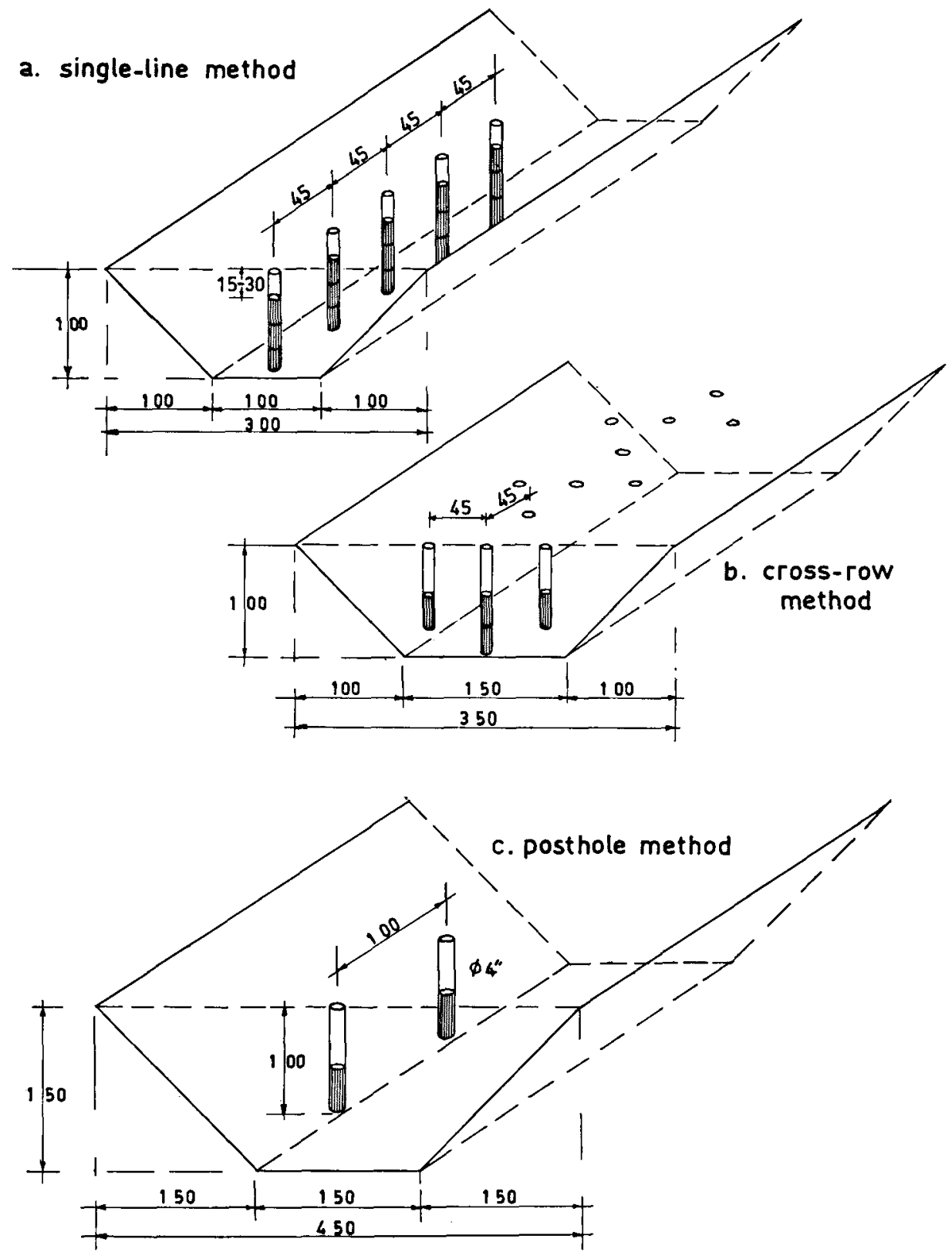

Postholing was used successfully to blast through ridges $1.8 \mathrm{~m}$ above the surrounding swamp, with loads up to $15 \mathrm{~kg}$ in $1.5-1.8 \mathrm{~m}$ deep bore holes spaced up to $1.5 \mathrm{~m}$ apart (see FIG. 14). 
All loading systems in ditch-blasting will remove stumps, boulders, logs, etc. but obviously such obstructions require an additional charge, varying from a few extra cartridges in the nearest charge-hole to a charge of several pounds in a separate hole under the stump or a row of DD sticks along the buttresses. These separate charges must be connected to the main line by a row of DD cartridges spaced at the proper interval to ensure ignition by propagation.

To develop full strength the explosive must be closely confined in the charge hole. Therefore the charge is tamped down and stemmed by refilling the hole with earth. In wet work like the Surinam swamp forest ditch-blasting, the holes rapidly fill with water and no further stemming is required. A primer cartridge must never be tamped.

\subsubsection{Firing the blast}

Propagation-fired blasts are ignited by means of a "primer" loaded somewhere in the row of charges. A primer consists of an electric or ordinary blasting cap and

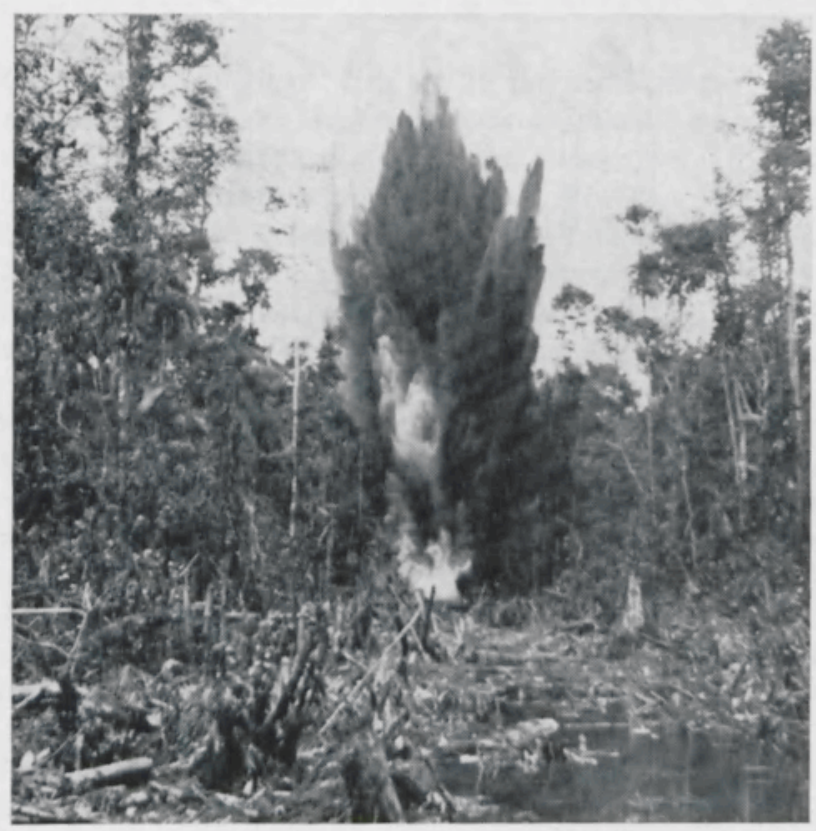

FIG. 9

The blast

fuse, inserted into a dynamite cartridge. The different methods of preparing a primer are described in detail in the various handbooks on blasting.

Individually ignited charges are fired electrically or with detonating fuse. Detonating fuse, in turn, is ignited either with an electric blasting cap or with a common cap and fuse.

For reasons of safety workmen, tools and surplus explosives must be removed to at least $100-150 \mathrm{~m}$ from the blast area. In the moist swamp-forest soil of Surinam materials from the blast are seldom thrown more than about $50 \mathrm{~m}$ from the ditch, but stones or gravel, if present in the soil, may be propelled considerably farther.

After the primer is loaded the safety fuse is trimmed and lit and the blaster hastily retreats to a safer position. 


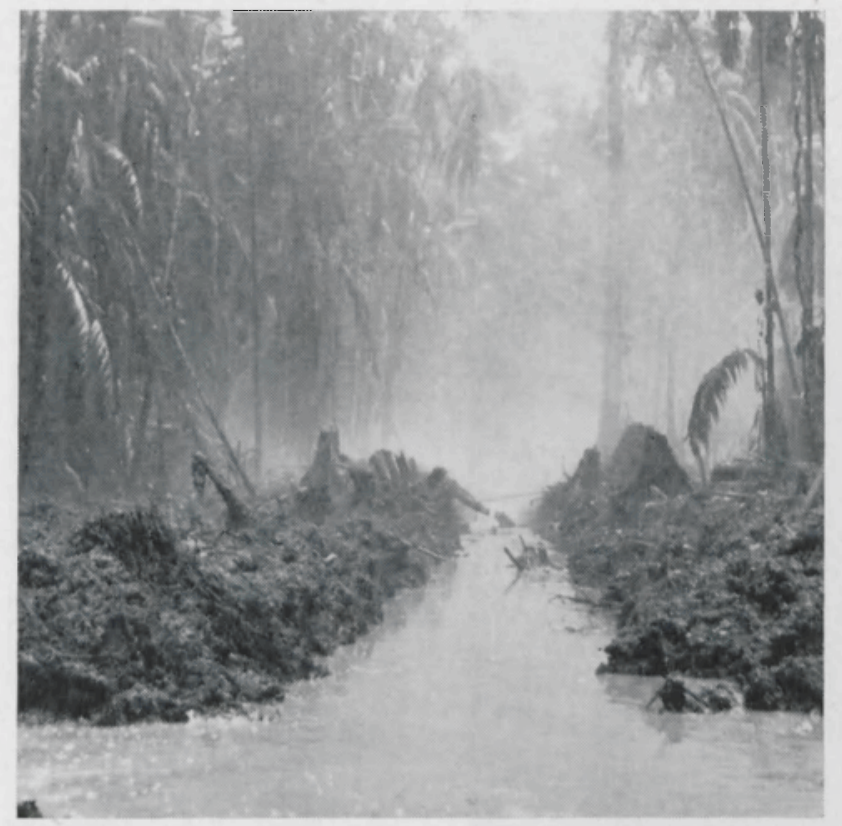

FIG. 10

Results of blasting through clay, in a $10-\mathrm{m}$ wide track, in the perica stand. Trunks and other debris are removed by hand or with portable winches

After the blast (FIG. 9) all personnel should wait for smoke and dust to settle before going near the blast area. The fumes of dynamite are toxic, causing severe headaches. Only very few misfires have occurred in the entire Forest Service blasting program. In wet work like ditch-blasting, misfires are usually caused by improperly seated or badly crimped caps or by damaged or moist fuse.

Misfires should not be approached for at least one hour, after which time it is considered safe to return and reshoot the charge.

Although DD and RC $50 \%$ are water-resistant they will deteriorate when left in water for a considerable time. Accordingly it is not advisable to leave a loaded section overnight, because, even though the dynamite will usually ignite after one or even two days in water, propagation may be incomplete and part of the charge may fail to detonate.

\subsubsection{Ditch cleaning}

The explosion forms a V- or U-shaped trench in the soil, which slowly or rapidly fills with water, according to the prevailing height of the water table and the porosity of the soil. In the wet Surinam swamps the new trench is filled almost immediately. Depending on soil and vegetation (FIG. 11) the ditch will be fairly clean or require yet much work to remove lumps of clay, stumps, branches and floating debris (Cf. FIG. 10, 12 and 13). In Surinam it was found that deep and clean ditches can be blasted without difficulty where firm clay is found at or near the surface. In the stiff clay the banks of the ditch may be steep without risk of crumbling and a width of $3 \mathrm{~m}$ is adequate to maintain the required depth and bottom width of about $3 / 4-1 \mathrm{~m}$.

Blasting through soft, peaty soil results in shallow ditches that need much manual cleaning and deepening (FIG. 12). The peat is pulverized by the explosion into a 

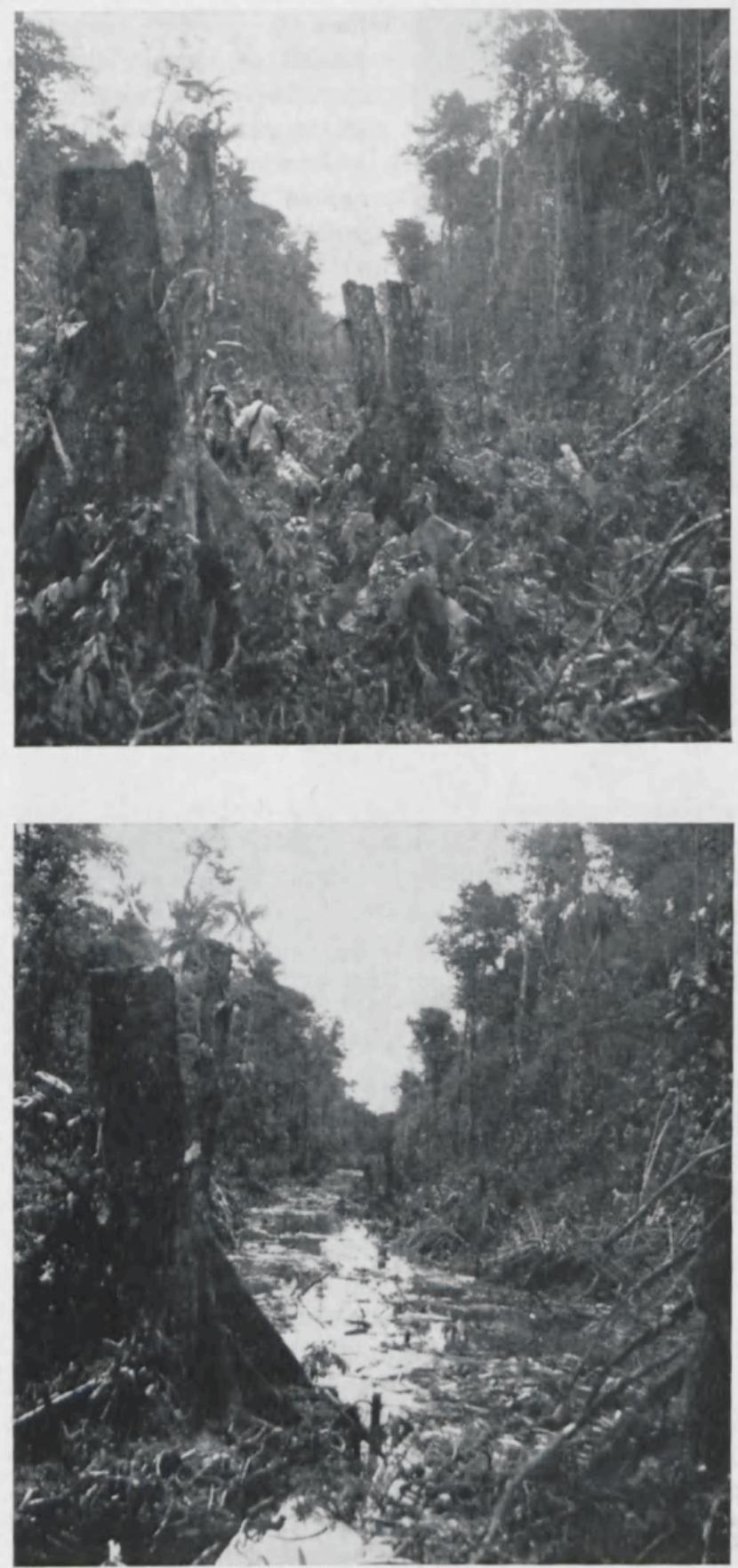

FIG. 11

Loading in progress in a $20-\mathrm{m}$ wide cleared track through peaty soil
FIG. 12

The same section as in FIG. 11 after blasting. The heavy, double symphonia trunk in the centre has completely disappeared (the virola stump in left foreground is outside the axis of the ditch).

This particular section went through deep pegasse with a densely-tangled root mat of symphonia stilt roots. As the photograph shows the resultant ditch is completely blocked by roots and floating peat. $C f$. the relatively clean, steep-banked ditch through clay in FIG. 10

sluggish suspension that flows back into the ditch or floats in dense masses on the surface. Only by allowing it to settle and by gradually cleaning and deepening the ditch by hand can an acceptable depth be attained. In the soft peat the natural gradient of the banks is gentle, for which reason the trench must be made wider 
Frg. 13. A string of virola peeler logs in the same ditch section (photograph taken from the virola stump on left foreground of FIG. 11 and 12)

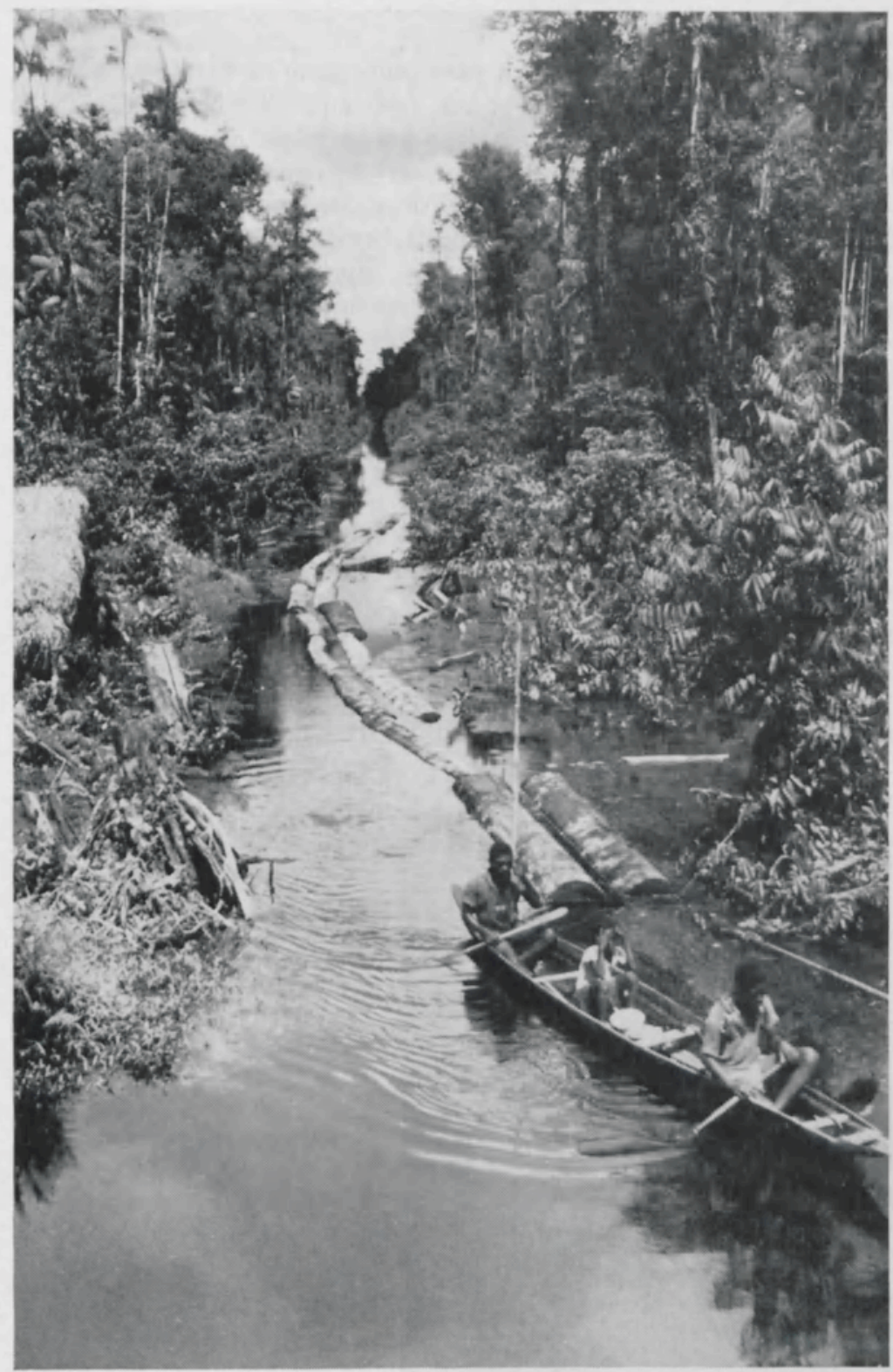

to obtain an adequate depth. Blasting through almost 2-m high ridges is succesfully performed by means of the posthole method (FIG. 14).

The Forest Service ditches must be suitable for $\log$ transportation as well as traffic with small out-boards, since all personnel and materials for the project must move 
through them. A fairly complete cleaning is required, effected by workmen equipped with shovels, rakes and light, hand-operated winches. Stubborne obstacles are removed by blasting.

\subsection{Personnel, safety measures}

The Forest Service ditch-blasting was done by a permanent gang of carefully selected, reliable workmen. The old adage "familiarity breeds contempt" is fully applicable to working with dynamite. The labourers are apt to grow careless after a while and constant supervision of all stages of the work is necessary to counteract this tendency. Not one accident has occurred in the course of the Forest Service ditch-blasting work. All dynamites tend to cause headache when handled, because nitroglycerine widens the blood vessels. According to Surinam experience the workmen gradually build up some immunity against this unpleasant side-effect of dynamite, though some persons are more sensitive than others. The use of workmen's gloves goes some way to eliminate the headache nuisance.

Each case of explosives contains a list of "Do's" and "Don'ts" and complete information will be found in any handbook on blasting. The rules on storage (special, locked powder house) transportation (in wooden vessels or wooden-bodied trucks, caps and explosives never close together), and handling are mainly self-evident and need not be elaborated here.

\subsection{Construction costs}

The following cost-breakdown of Surinam ditch-blasting might be modified to suit local soil, vegetation and working conditions. It must be kept in mind that the access ditches were made in extensive, inaccessible and uninhabited swamp forest and that all personnel and explosives had to be moved in from elsewhere through the

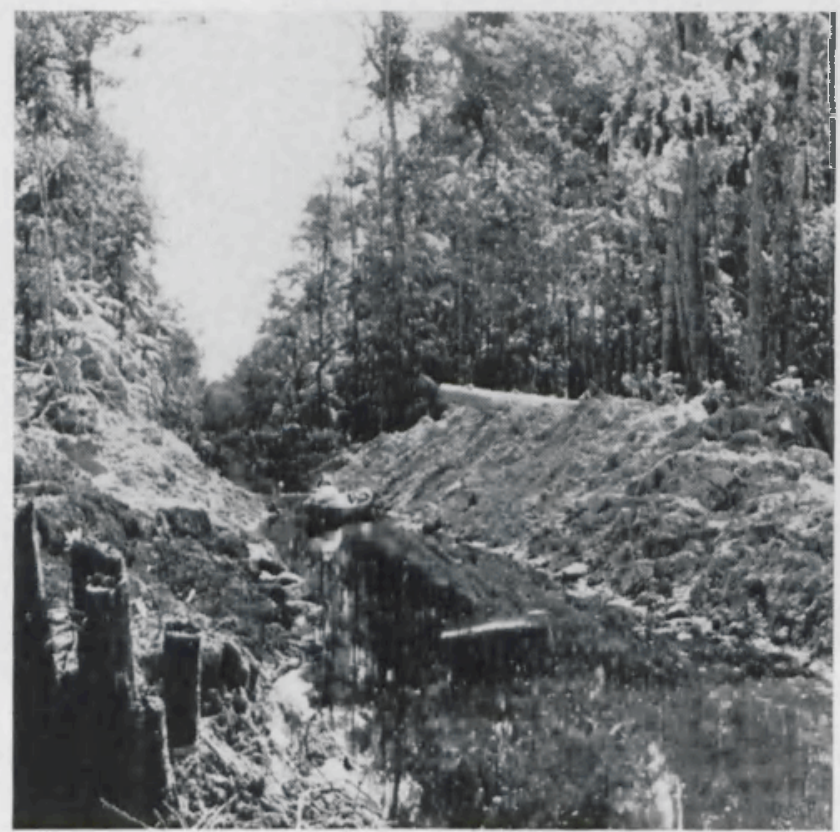

FIG. 14

Result of posthole blasting through an almost 2-m high ridge. This $120 \mathrm{~m}$ stretch required 31 cases of dynamite $(50 \mathrm{lb}$.) 
TABlE 2. Specification of construction costs 1962 in $\%$

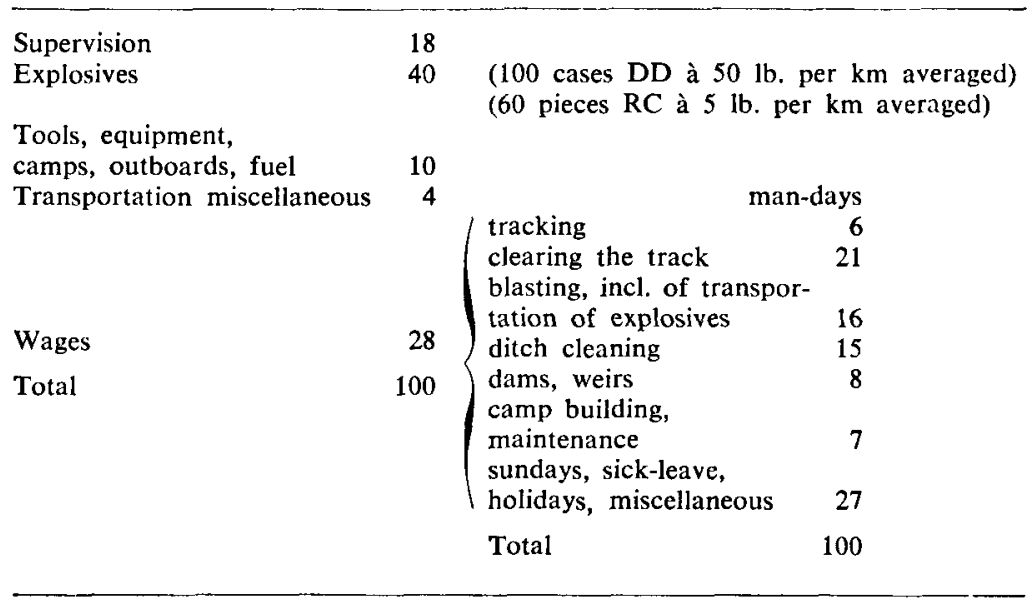

ditches. Construction of camp sites was expensive and much working time was lost in travelling and transport.

Some basic Surinam cost figures, to allow comparison with local prices:

Laborers wages, incl. subsistence allowance etc. 6-7 Sf

$\begin{array}{ll}\text { DD } 50 \% \text {, per case }(50 \mathrm{lb} .) & 32 \mathrm{Sf} \\ \text { RC } 50 \% \text {, per case }(50 \mathrm{lb} .) & 24 \mathrm{Sf}\end{array}$

Fuse and caps, a few cents per foot or per piece -

All-in costs (excluding depreciation and interest charges on camps etc.) of the Forest Service ditches have varied from ca. Sf 5500 to ca. Sf 7500 per $\mathrm{km}$. The figures below refer to 1962, when operations were in full swing $(16.2 \mathrm{~km}$ of ditch were blasted in 1962) and the technique had been perfected.

Construction cost 1962, project Perica: Sf 5550 per $\mathrm{km}$ ( $=$ US $\$ 4800$ per mile). A specification is given in TABLE 2. As apparent from the given figures, explosives are always the major cost item in ditch-blasting.

\section{Ditch maintenance}

\subsection{The blocking process}

Even in the opened-up swamp forests logging is confined to the rainy seasons, when the loggers are able to construct shallow trenches through the inundated swamp with little effort in order to float out the felled logs to the extraction ditches (FIG. 15). To prevent the water from draining away too rapidly and to extend the timber exploitation into the dry season, permanent weirs with removable wooden gates (FIG. 16 and 17) are built in the exit channels. During the rainy seasons the gates are partly opened to create a steady current in the ditches which aids in the floating out of the logs and cleans the channel by its scouring action. When the rains abate and the water level starts to drop, the gates are closed. 

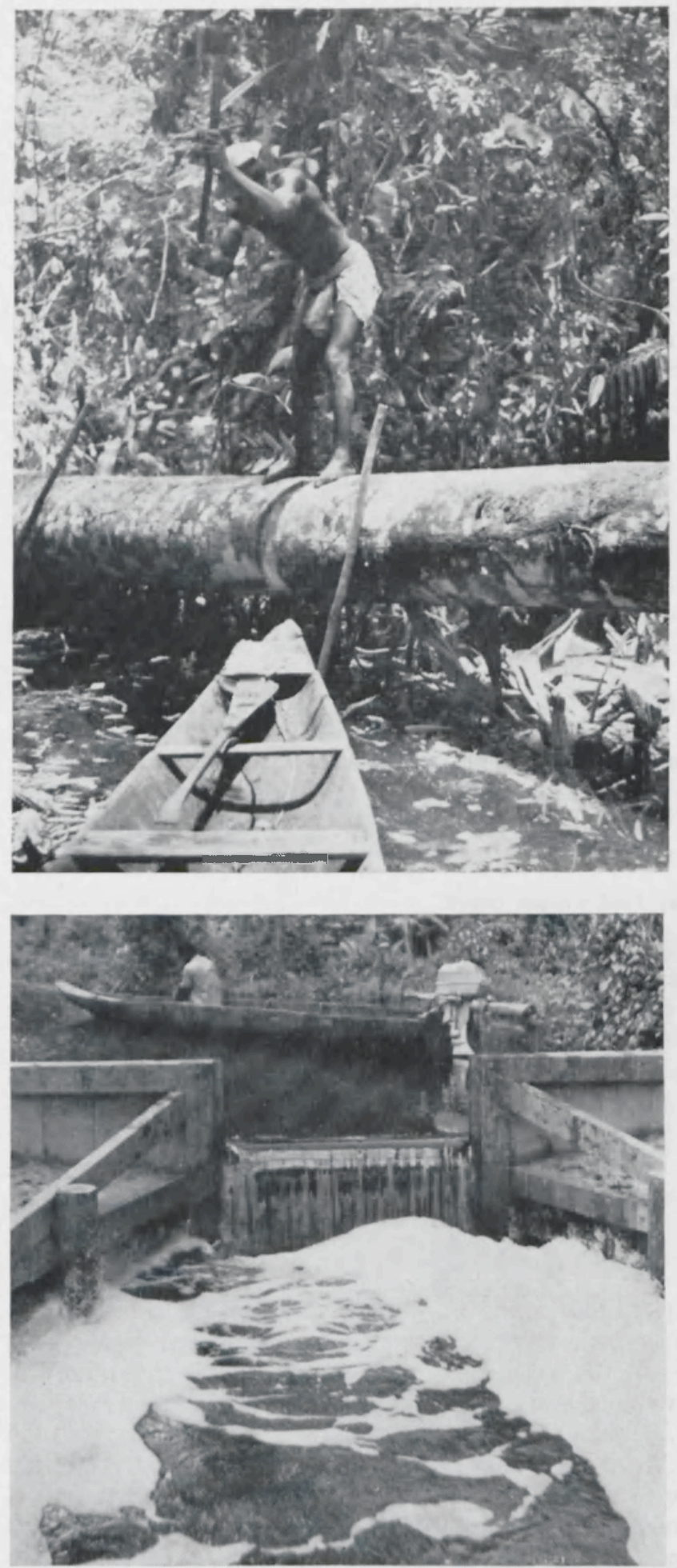

Fig. 15

Logger crosscutting a virola peeler $\log$ in swamp. The logs are floated out through a shallow, hand-dug trench to the main extraction ditch

FIG. 16

Permanent weir and floodgate in the main exit of the "Perica" ditch system. The gate consists of $3 \times 10^{\prime \prime}$ tongued and grooved planks which move between $2 \mathrm{U}$ beams. Water flow is regulated by removing or placing planks as required 
FIG. 17. Plan of a permanent weir and gate in the exit channel of the "Perica" ditch system (all dimensions in $\mathrm{mm}$ where not in inches; 1 inch $=25.4 \mathrm{~mm}$ )

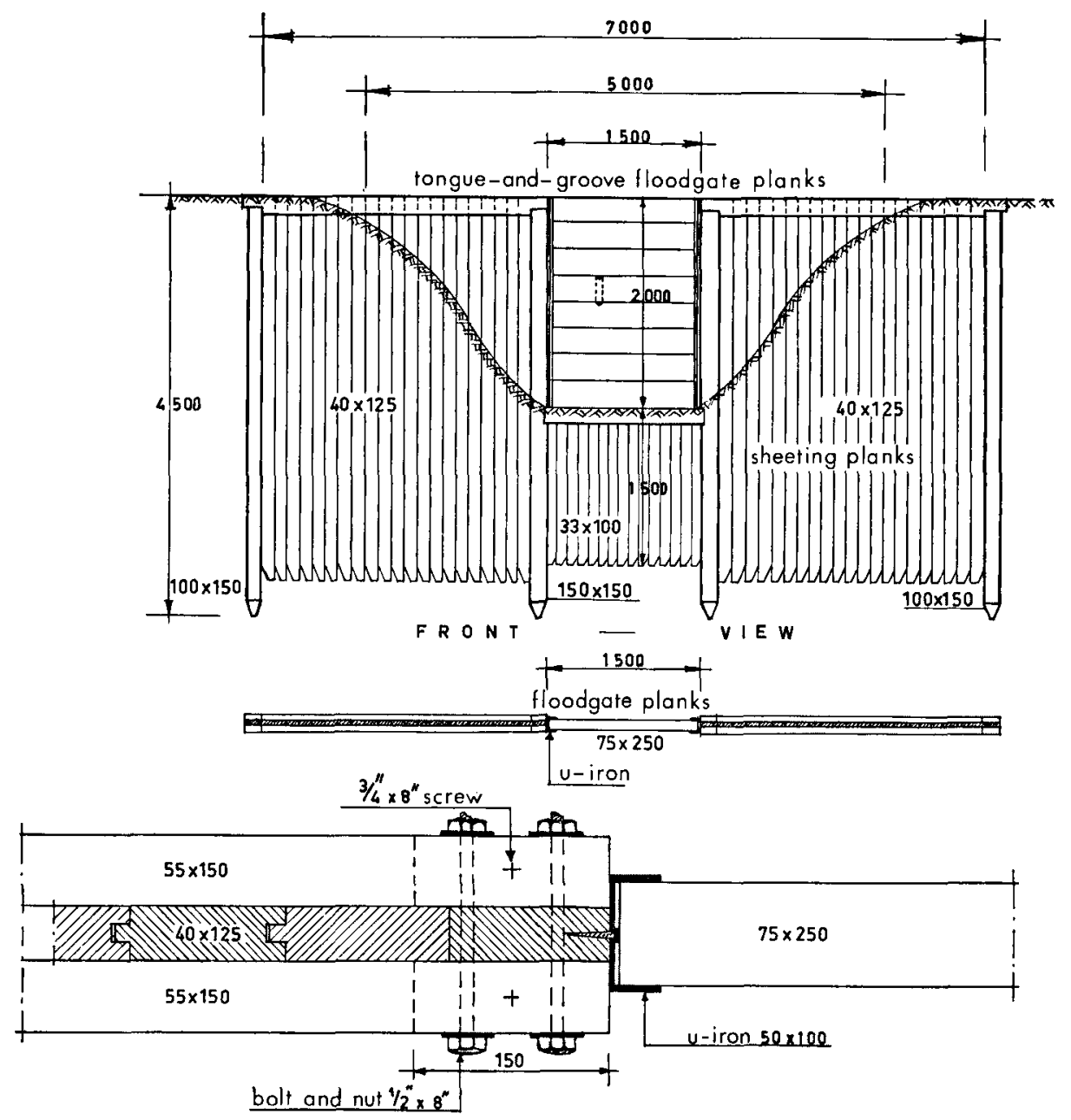

From the middle of the dry season shallow sections of the ditches run dry and weeds start growing. Some are killed by subsequent inundation, others maintain their foothold. In the stagnant water aquatic weeds soon appear. Litter from the swamp forest, from leaves to entire trunks, aids in the blocking process. If the ditches are to remain navigable for more than just one or two logging seasons, they must be maintained.

Soil conditions determine to a large extent the type of vegetation in the ditch and thereby the amount of maintenance work required.

The ditch sections through pegasse, already shallow to start with, silt up further by the action of the rains and the water disturbance created by passing boats. Aquatic weeds, like water lilies (Nymphoides sp.) and Sara sara grasi (Cabomba sp.) grow profusely, the latter eventually forms dense (up to $20 \mathrm{~cm}$ ) floating mats, which in turn are colonized by grasses and rushes. 
In the steep-banked, deep ditch sections through clay, silting up is negligeable and aquatic weeds are less troublesome although the same species from the pegasse areas are found in places. Grasses and sedges sprout on the banks and gradually extend into the ditch. The rapidly developing secondary growth, mainly consisting of largeleaved pioneer species like Cecropia and Heliconia, forms a dense overhead shade within a few years, causing the gradual disappearance of the aquatic weeds, which demand full sunlight.

Luckily, the dreaded water hyacinth has not made its appearance in the ditches so far, although it is found in Surinam.

\subsection{C l e a n ing}

Obstructions like fallen branches and trunks are removed by hand. Weeds are removed by manual labour or by spraying with herbicides. Against aquatic weeds "Silvex" (a 2-2,4,5-trichlorophenoxy propionic acid formulation) was found effective.

This herbicide is simply sprayed on or in the water, with a knapsack sprayer, at a rate of $8-9$ litre per $\mathrm{km}$ of ditch. Where much grass is present a mixture of $400 \mathrm{~g}$ "Dalapon" (sodium 2,2 dichloropropionate) per litre "Silvex" is used. The herbicide may be diluted with water for easier spraying. Chemical weed control is undertaken in the beginning of the dry season, when the ditches are still navigable but the herbicide will not be diluted immediately by fresh swamp water. For obvious reasons chemical weed control is out of the question if the ditches are the only supply of drinking water for loggers and blasting or cleaning crews.

"Silvex" costs about Sf 5.- per litre, so spraying costs work out at Sf $40-45$ per $\mathrm{km}$ (exclusive of labour). Manual removal of weeds, the only solution in completely blocked ditch sections, requires $25-30$ effective man-days per $\mathrm{km}$ or $\mathrm{Sf} 250-300$ per $\mathrm{km}$.

It is already apparent that the ditch sections through pegasse will not last for more than a few years. Reblasting or deepening by mechanical means will be necessary if they are to be kept open. In clayey soil the ditches will probably last for a considerable time with only a minimum of maintenance, once an overhead canopy has become established and aquatic weeds become less troublesome.

Regular $\log$ extraction and a steady water flow through the ditches will keep them free from obstructions. For that reason blasting should proceed apace with exploitation, no new section being constructed until the forest along the proceeding section has been exploited completely.

\section{B I B L I O G R A P H Y}

Anon

EIJK, J. J. VAN DER

LindEMAN, J. C., and S. P. MoolenaAR

Surinam Forest Service VINK, A. T.

VOORDE, P. K. J. VAN DER
1962 Creusement des fossés à la dynamite. Centre Technique Forestier Tropical. Rec. techn. Exploitation forestier. 1.

1958 Du Pont Blasters' Handbook. Du Pont de Nemours \& Comp. Inc., Wilmington, Delaware, U.S.A.

1954 De landschappen van Noord Suriname. Centraal Bureau Luchtkartering, Paramaribo. Publ. No. 15.

1959 Preliminary survey of the vegetation types of northern Surinam. In : The Vegetation of Surinam. Vol. 1, part 2.

1958-1963 Ann. Report, 1958-1963. Paramaribo.

1964 Ditching with dynamite. Surinam Forest Service Stencil.

1957 De bodemgesteldheid van het ritsenlandschap en van de oude kustvlakte in Suriname. Amsterdam. 